\title{
The Effectiveness of Social Media Utilization in Learning at Elementary School
}

\author{
Gita Vinnie', $^{1}$ M. Muktiarni ${ }^{2, *}$, Jonah Mupita ${ }^{3}$ \\ ${ }^{1}$ Departemen Pendidikan Bahasa Perancis, Universitas Pendidikan Indonesia, Indonesia \\ ${ }^{2}$ Departemen Pendidikan Ekonomi, Universitas Pendidikan Indonesia, Indonesia \\ ${ }^{3}$ Ruya Adventist High School, Zimbabwe \\ *Corresponding author : muktiarni@upi.edu
}

\begin{abstract}
Abstrak: Proses pembelajaran siswa di Indonesia telah berubah setelah pandemi Covid-19 yang berasal dari Wuhan, China dan hampir menyebar ke seluruh wilayah di dunia. Pemerintah telah memutuskan untuk membatasi kegiatan sosial, menyerukan menjaga jarak antara satu sama lain dalam beraktivitas, dan menghindari keramaian. Hal ini dilakukan dalam rangka mengurangi jumlah penyebaran virus Covid-19 di Indonesia. Dampak dari kejadian ini bagi pendidikan di Indonesia, pembelajaran yang awalnya berlangsung tatap muka sekarang harus dilakukan secara daring. Makalah ini menguraikan tentang keefektifan penggunaan platform media sosial seperti YouTube dalam pembelajaran daring untuk siswa sekolah dasar selama pembelajaran daring. Kegiatannya berupa pemberian materi Bahasa Indonesia melalui media daring kepada siswa SD 247 Sukapura Kota Bandung. Hasil kegiatan menunjukkan bahwa penggunaan media sosial dalam pembelajaran dapat meningkatkan literasi digital siswa SD. Kuesioner yang didistribusikan kepada para siswa yang terlibat memperlihatkan adanya peningkatan pemahaman setelah diberikan materi pembelajaran melalui aplikasi Zoom dan menggunakan media sosial seperti YouTube.
\end{abstract}

Kata Kunci: pembelajaran daring, literasi digital, pandemi.

\begin{abstract}
The learning process of students in Indonesia has changed after the Covid-19 pandemic that originated in Wuhan, China and has almost spread to all regions of the world. The government has decided to limit social activities, call for social distancing, and avoid crowds. This is done in order to reduce the spread of the Covid-19 virus in Indonesia. The impact of such condition on education in Indonesia, learning that initially took place face-toface now has to be done online. This paper describes the effectiveness of using social media platforms such as YouTube in online learning for elementary school students during online learning. The activity is in the form of providing Indonesian language materials through online media to elementary school students of SD 247 Sukapura, Bandung. The results of the activity show that the use of social media in learning can improve the digital literacy of elementary school students. Based on the questionnaires which distributed to the students showed an increase in understanding after being given learning materials through the Zoom application and using social media such as YouTube.
\end{abstract}

Keywords : online learning, digital literacy, pandemic.

Volume 2, Nomor 2, Oktober 2021| 164

The Effectiveness of Social Media Utilization in Learning at Elementary School

Gita Vinnie, M. Muktiarni, Jonah Mupita

https://doi.org/10.26874/jakw.v2i2.129 


\section{Introduction}

The Covid-19 was first identified on December 2019 and recently being pandemic. The impact from this Covid-19 pandemic not only in the health sector but also in other aspects like education, economy, sports, etc. The government decided for new rules to keep us safe from this pandemic such as social distancing, avoid crowds, and so on. However, education cannot be stopped because the education has a very important role in developing of quality human resources (Mujianto, 2019). The education is a place to find, bring up, and develop the potential that exists in every child which is carried out intentionally and planned through a process of guidance activities, guidance to children so that they have intelligence, emotional and spiritual intelligence to be equipped to live life in a community environment in the future (Ramdhani, 2017). The negative impact of Covid-19 pandemic for education are closed for school, madrasah, university and pondok pesantren (Setiawan, 2020). The government decided to change the learning methods from face-to-face learning to online learning. Fuadi et al. (2020) explains that online learning refers to use of internet technology to deliver a series of solutions that can improve knowledge and skills. Information technology can be accepted as a medium in carrying out the educational process, which also involves searching for references and sources of information (Wekke \& Hamid, 2013). By online learning, the students could access Youtube website (as one of the social media) to look for the answer they don't understand because Youtube platform given facility for its users to freely access (Sianipar, 2013). Especially for elementary school, the role of teachers and parents is crucial to guide the students in information technology utilization. As we known, social media has a bad influence and it can be addiction for student if we don't pay attention more. This paper discusses how to use digital literacy in elementary school student learning during online learning. Literacy is also not just reading and writing, literacy is meaningful in practice and social relations related to knowledge, language, and culture (Teguh, 2020). It has been stated that technological developments provide changes to the implementation of teaching and learning (Keengwe \& Georgina, 2012). The research question which solved in this study includes how do schools use the Zoom meeting applications for improving digital literacy, are there any obstacles from students when learning to use the application, and when reading, counting, and writing lessons using the application can students follow well or not.

Volume 2, Nomor 2, Oktober 2021| 165

The Effectiveness of Social Media Utilization in Learning at Elementary School

Gita Vinnie, M. Muktiarni, Jonah Mupita

https://doi.org/10.26874/jakw.v2i2.129 
Jurnal Abdimas Kartika Wijayakusuma ISSN 2716-3512 (Online) ISSN 2721-0367 (Print)
This work is licensed under a Creative Commons

Attribution-ShareAlike 4.0 International License.

CC BY SA

\section{Methods}

The method for this study is descriptive quantitative, online analysis to know the opinion from the students, and problem solving. All methods were used to analysis the system in online learning at elementary school. This activity involved 6th graders of SD 247 Sukapura, Bandung.

\section{Results and Discussion}

The activity was done through Zoom meeting application. As shown in Figure 1, almost 30 students involve in the class for Indonesia language, while the teacher given them an example text to read and to determine $5 \mathrm{~W}+1 \mathrm{H}$ or means (what, who, where, why, when, and how). The assignment the teacher gave to know the students understood and pay attention while the class in direct or not. Figure 2 shows the number of students who were involved in the activity and who filled out the questionnaire.
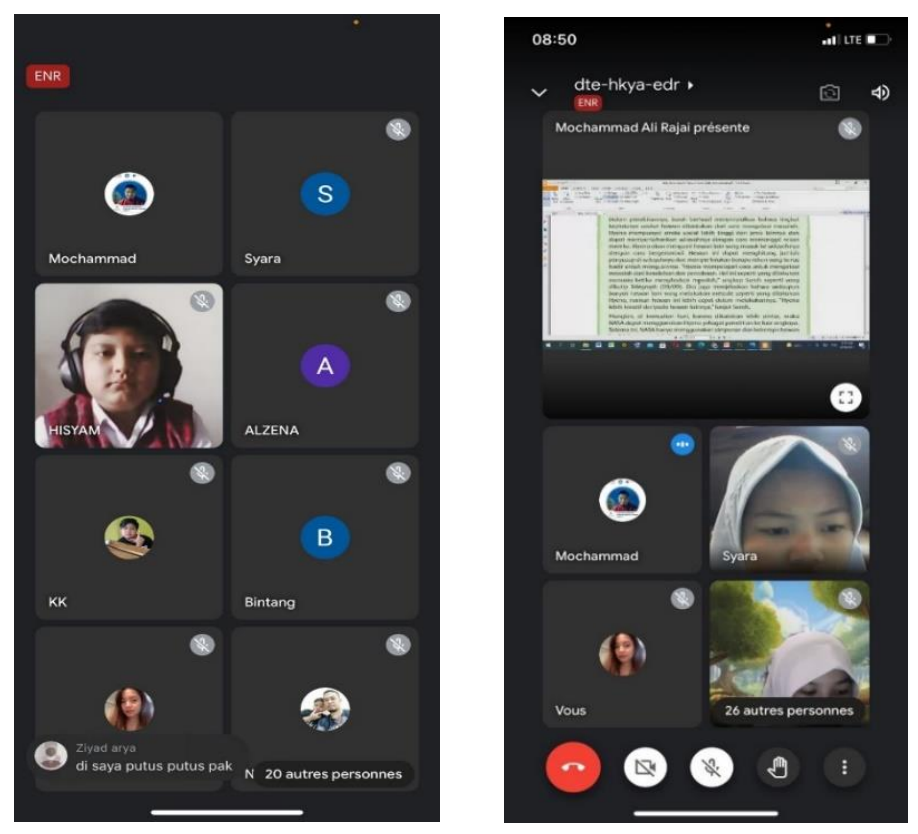

Figure 1. A snapshot of the activity through Zoom meeting Application

Based on observation, some students did not understand and cannot decide the results from the text. Their parents sat next to them for helped their child to understood the subjects. Disturbances in the teaching and learning process directly between teacher and students as well as the termination of the assessment of learning have an impact on the psychological students 
Jurnal Abdimas Kartika Wijayakusuma ISSN 2716-3512 (Online) ISSN 2721-0367 (Print)
This work is licensed under a Creative Commons Attribution-ShareAlike 4.0 International License.

(Aji, 2020). It was observed that some parents helped their children do their homework. This is example for the negative impact by online learning. When students were asked about how online learning was, they found it difficult to learn some subjects such as math and science. They reasoned that the teachers only provided materials and exercises without giving explanations. Covid-19 pandemic has various problems which experienced by teachers (Asmuni, 2020). The students have to look for answers from books or through Youtube and find it difficult to do the assignments given by the teacher. However, they can follow and understand the Indonesian language lesson well, because they use the language daily. During activity through Zoom meeting application, they found no significant difficulties except for interruptions when the network connection was lost. To support the online learning process, each student receives financial support to purchase a data package every month.

Table 1. Pre-test and post-test results

\begin{tabular}{|c|l|c|c|c|}
\hline No. & \multicolumn{1}{|c|}{ Question } & Pre-Test & Post-Test & Gain \\
\hline 1. & $\begin{array}{l}\text { How about online learning } \\
\text { during this pandemic? }\end{array}$ & $30.2 \%$ & $35.8 \%$ & $5.6 \%$ \\
\hline 2. & $\begin{array}{l}\text { Is subject Indonesian language } \\
\text { difficult for you? }\end{array}$ & $50.3 \%$ & $65.0 \%$ & $9.7 \%$ \\
\hline 3. & $\begin{array}{l}\text { How about writing, reading, } \\
\text { counting through Zoom? Is it } \\
\text { easy? }\end{array}$ & $34.7 \%$ & $35.6 \%$ & $0.9 \%$ \\
\hline 4. & $\begin{array}{l}\text { The distance makes you difficult } \\
\text { to understand the subject? }\end{array}$ & $70.1 \%$ & $68.10 \%$ & $-1.91 \%$ \\
\hline 5. & $\begin{array}{l}\text { Do homework without explain } \\
\text { makes you confused? }\end{array}$ & $83.2 \%$ & $80.1 \%$ & $-3.1 \%$ \\
\hline
\end{tabular}

To measure the effectiveness of using social media in online learning, five questions were given to students before and after the learning process as listed in Table 1. For question number one, $30.2 \%$ of respondents stated that they had learning difficulties due to the pandemic situation. However, the number of students who understand the pandemic conditions and benefit from the use of social media during online learning during the pandemic has increased to $35.8 \%$. For question number two, only $50.3 \%$ of students did not find it difficult to learn the Indonesian language lesson even though the teacher only gave assignments without giving 
Jurnal Abdimas Kartika Wijayakusuma ISSN 2716-3512 (Online) ISSN 2721-0367 (Print)
This work is licensed under a Creative Commons Attribution-ShareAlike 4.0 International License.

explanations. However, after being given material through the Zoom application, students who felt that Indonesian language lesson were easy to learn rose to $65 \%$.

For question number three, $34.7 \%$ of respondents find difficult for mathematics, they really didn't understand. Meanwhile, after using YouTube for support the learning, 35.6\% of students find it easy to learn topics in mathematics and science. For question number four, Initially, nearly $70.1 \%$ of students felt distance was an obstacle in learning, but after being given an understanding of the benefits of online media in learning the number of students who felt distance was an inhibiting factor decreased to $68.1 \%$. Furthermore, for the last question, the percentage of students who find it difficult to do assignments without an explanation from the teacher decreases from $83.2 \%$ to $80.1 \%$ after using online media such as YouTube.

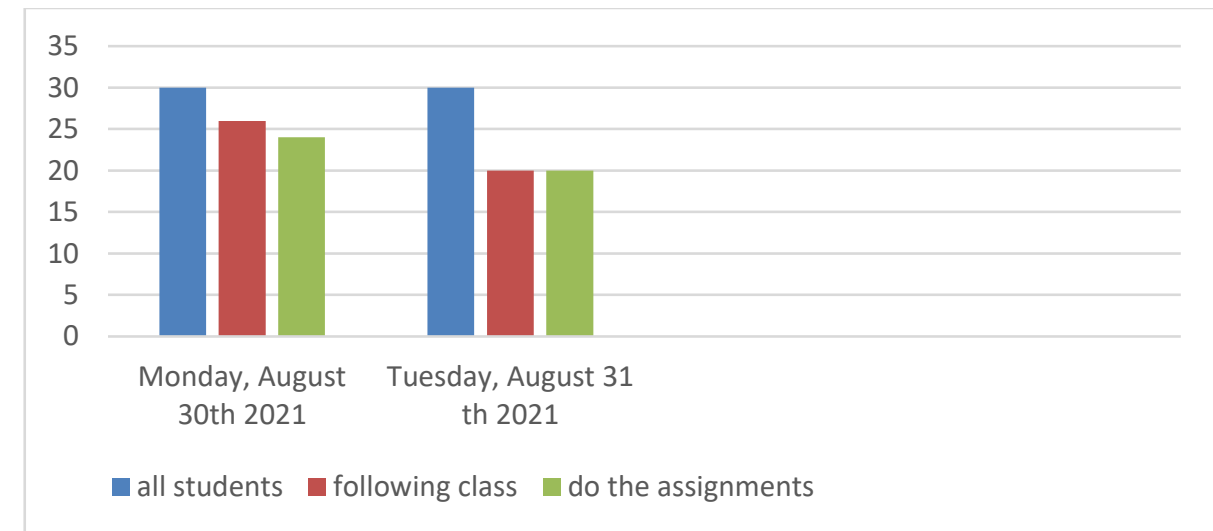

Figure 2. The number of students who were involved in the activity and who filled out the questionnaire.

The observations concluded that the use of social media such as YouTube is effective in helping the online learning process. However, it requires a guidance or accompanied by teachers and parents.

\section{Conclusion}

The education is really important for all humans in the world, no matter what the situations are. The Covid-19 pandemic has forced the change of learning methods from offline to online. Learning can take place effectively by using social media such as YouTube which provides a variety of learning content according to needs. The results of observations from the activities carried out concluded that students were generally benefited in online learning by utilize a 
social media platform. However, the role of parents and teachers is needed in guiding the use of social media.

\section{Acknowledgements}

We would like to thank LPPM Universitas Pendidikan Indonesia for helping me to organizing the lecture activities as well the instructions that really meaningful for me. We also acknowledge to M. Ali Rajai, M.Pd. from SD 247 Sukapura, Bandung for giving us a chance to join class and do the analysis for the students. This activity is a part of community service (program: KKN Tematik Literasi 2021 (August-September 2021). We also thank to Kantor Jurnal dan Publikasi, Directorate of International Affairs, Universitas Pendidikan Indonesia.

\section{References}

Aji, R. H. 2020. Dampak Covid-19 pada pendidikan di Indonesia: sekolah, keterampilan, dan proses pembelajaran. Salam: Jurnal Sosial dan Budaya Syar'i, 5(7), 395-402.

Asmuni, A. 2020. Problematika pembelajaran daring di masa pandemi Covid-19 dan Solusi pemecahannya. Jurnal paedagogy, 7(4).

Fuadi, T, M., Musriandi, R. \& Suryani, L. 2020. Covid-19 : Penerapan pembelajaran daring di perguruan tinggi. Dedikasi Pendidikan, 4(2), 193-200.

Keengwe, J. \& Georgina, D. 2012. The digital course training workshop for online learning and teaching. Education and Information Technologies, 17(4), 365-379.

Mujianto, H. 2019. Pemanfaatan youtube sebagai media ajar dalam meningkatkan minat dan motivasi belajar. Jurnal Komunikasi Hasil Pemikiran dan Penelitian Program Studi Ilmu Komunikasi, Universitas Garut, 1(5), 10-25.

Ramdhani, M.A. 2017. Lingkungan pendidikan dalam implementasi pendidikan karakter. Jurnal Pendidikan UNIGA, 8(1), 28-37.

Setiawan, A.R. 2020. Lembar kegiatan literasi saintifik untuk pembelajaran jarak jauh topik penyakit corona virus (Covid-19). Edukatif: Jurnal Ilmu pendidikan, 2(1), 28-37.

Sianipar, A.P. 2013. Pemanfaatan Youtube di Kalangan Mahasiswa, Flow, 2(3), 85-91.

Teguh, M. 2020. Gerakan literasi sekolah dasar. Jurnal Pendidikan Dasar Flobamorata, 1(2), $1-9$.

Wekke, I.S. \& Hamid, S. 2013. Technology on language teaching and learning: A research on Indonesian pesantren. Procedia - Social and Behavioral Sciences, 83(17). 585-589.

Volume 2, Nomor 2, Oktober 2021| 169

The Effectiveness of Social Media Utilization in Learning at Elementary School

Gita Vinnie, M. Muktiarni, Jonah Mupita

https://doi.org/10.26874/jakw.v2i2.129 